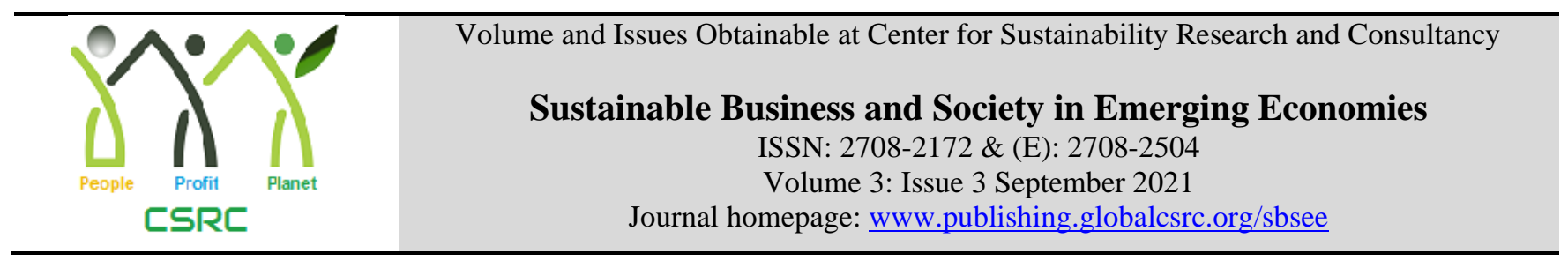

\title{
Inclusive Practices in the Existing School Environment: Parental Perceptions and Concerns
}

Laila Khalid, Special needs Education University of Management and Technology, Lahore Pakistan *Saima Malik, University of Management and Technology, Lahore Pakistan

Muhammad Zaheer Asghar, University of Management and Technology, Lahore Pakistan

Research Fellow, ICT \& Education (e-learning) Universitat Oberta De Catalunya, Barcelona Spa

*Corresponding author's email address: saimamalik666@yahoo.com

\begin{tabular}{l}
\hline ARTICLE DETAILS \\
\hline History \\
Revised format: Aug 2021 \\
Available Online: Sep 2021 \\
\hline Keywords \\
Inclusive practices, School \\
environment, Parental \\
perceptions, Children with \\
disabilities.
\end{tabular}

JEL Classification

12,120

\section{OPEN ACCESS}

\section{ABSTRACT}

Purpose: This qualitative research paper explores the factors affecting parental perceptions and concerns about inclusive education. It also investigates the factors influencing the access and participation of children with disabilities in mainstream schools.

Design/Methodology/Approach: Ten parents $(n=10)$ of children with and without disabilities were selected through purposive sampling from inclusive primary schools of Punjab. Semi-structured interviews and thematic analysis were employed for data collection and analysis.

Findings: Findings revealed that parents of children with disabilities are more inclined towards inclusive education. Reactions of parents, quality of instruction and institutional support have created a feeling of uncertainty and dissatisfaction amongst the parents of children with disabilities about inclusion. Large class sizes and time constraints have been established as barriers to inclusion.

Implications/Originality/Value: The study would be constructive for the school department to consider the factors adversely affecting the process of inclusion. Parents' guidance and counselling may be made mandatory to make inclusive education successful.

(C) 2021 The authors, under a Creative Commons AttributionNonCommercial- 4.0

\footnotetext{
Recommended citation: Khalid, L., Malik, S. and Asghar, M. Z. (2021). Inclusive Practices in the Existing School Environment: Parental Perceptions and Concerns. Sustainable Business and Society in Emerging Economies, 3 (3), 285-299.
}

\section{Introduction}

Inclusive education has emerged out as a drive aimed at changing discriminatory policies and exercises. It is progressively becoming the most effectual strategy for fulfilling the educational requirements of all students and guaranteeing that all children, regardless of their disabilities and impairments, have the right to education in regular school settings (Carrington, Bourke \& Dharan, 2012). Nevertheless, owing to a number of issues, including a low parental engagement in school decision-making processes, which is critical to the creation of laws to safeguard parents and their children in inclusive education, inclusive education remains a highly discussed topic (Alur \& Timmons, 2004). 
In Pakistan, inclusive education stays a dry field in education, with many unsolved issues, particularly about the perspectives, thoughts, and attitudes of parents with and without disabilities regarding inclusion (UNICEF, 2017). Only private sector, and that too, a small number of schools are catering diversity, however full inclusion model is rarely visible in those schools, too (UNICEF, 2003). It is important to study and understand the effects of inclusion keeping in view the well-being of abled children, children with special needs, parents/families and the teaching-learning process towards inclusion (Duhaney \& Salend, 2004).

Parents undoubtedly play a critical role in the lives of their children therefore investigation of the parents' views and fears is an important aspect regarding evaluation of the inclusion movement. According to Mapolisa and Tshabalala, (2013) parents show apprehension about the institutional and related professionals' support for the enhancement of cognitive and social skills of children with disabilities. The level of satisfaction of the parents rely on regular counselling and parents-teachers along with flexible curriculum (Pomerantz, Moorman, and Litwack, 2007). Parents of children without disabilities feel uncomfortable due to the presence of children with disabilities in the classrooms (Ehsan, 2018).

However, necessary issues including parents' attitudes and concerns need to be addressed in order to bridge the gap between the theory of inclusion and its application in the existing learning environment of the country. The purpose of this study was to examine the parents' perceptions and concerns of children with and without disabilities towards inclusive education and the factors influencing the access and participation of children with disabilities in inclusive settings at primary level.

\section{Objectives of the Study}

1. To explore the parents' concerns about inclusive education.

2. To investigate the factors affecting the attitudes and perceptions of parents with and without disabilities about inclusive education settings.

3. To determine the factors influencing the access and participation of children with disabilities in inclusive education.

\section{Significance of the Study}

The findings of the study are expected to contribute considerably to the corpus of knowledge on present inclusive practices in primary schools. The study would undoubtedly deliver information on parental attitudes and beliefs toward inclusive education, as well as their responsibilities in bolstering inclusive policies in schools. The study would likely help to evaluate the parental attitudes and perceptions of children with and without disabilities about inclusion with an emphasis to resolve those through parents' guidance and counselling. Findings of the study has established the significance of parental guidance and counseling, and would make the stakeholders realize its importance and usefulness to promote inclusion. The study has highlighted the gaps in the quality of instruction and available institutional support to make the schools administration revisit their existing inclusive practices and to move towards making a viable plan in augmenting the process of inclusion in primary schools.

\section{Literature Review}

Inclusive education approach is an emerging concept that advocates in including all children in mainstream education irrespective of their religion, culture, language, ability/disability, etc. (UNESCO, 2009). According to a report by UNESCO, (2003) the status of inclusive education is not satisfactory in Pakistan, as the government is not supporting inclusion. A small number of inclusive schools are operating in urban cities of Pakistan, and these are not accessible to children with disabilities of remote or rural areas, which cover the larger disabled population (UNICEF, 2017). The schools, in urban areas, or less urban areas are mostly run by the private sector and NGOs. Those schools are also struggling to create an inclusive environment through experimentation of various approaches (Farooq, 2012).

Unfortunately, no desired outcome is visible in the implementation of inclusive education so far in the public sector in the country (Singal, 2018). Factors like parents' perceptions; untrained teachers; rigid 
curriculum and teaching techniques; absence and shortage of learning material, and assistive devices also contribute to preventing inclusive education approaches in the schools of Pakistan (Hameed, 2009; Singal, 2018).

According to Mitchell, (2015) inclusive education is a multi-faceted concept. Inclusive education is a concept whose time has come throughout the world, the driving force behind it is UN Convention on the Rights of People with Disabilities. Its range has now been expanded to include all learners with special education needs, regardless of their backgrounds. It also goes beyond simply placing such students in typical and regular classrooms to take into account a variety of educational considerations. Criteria

are given and indicators are proposed for each of these dimensions. The model of inclusive education by Mitchell (2015) is as follows:

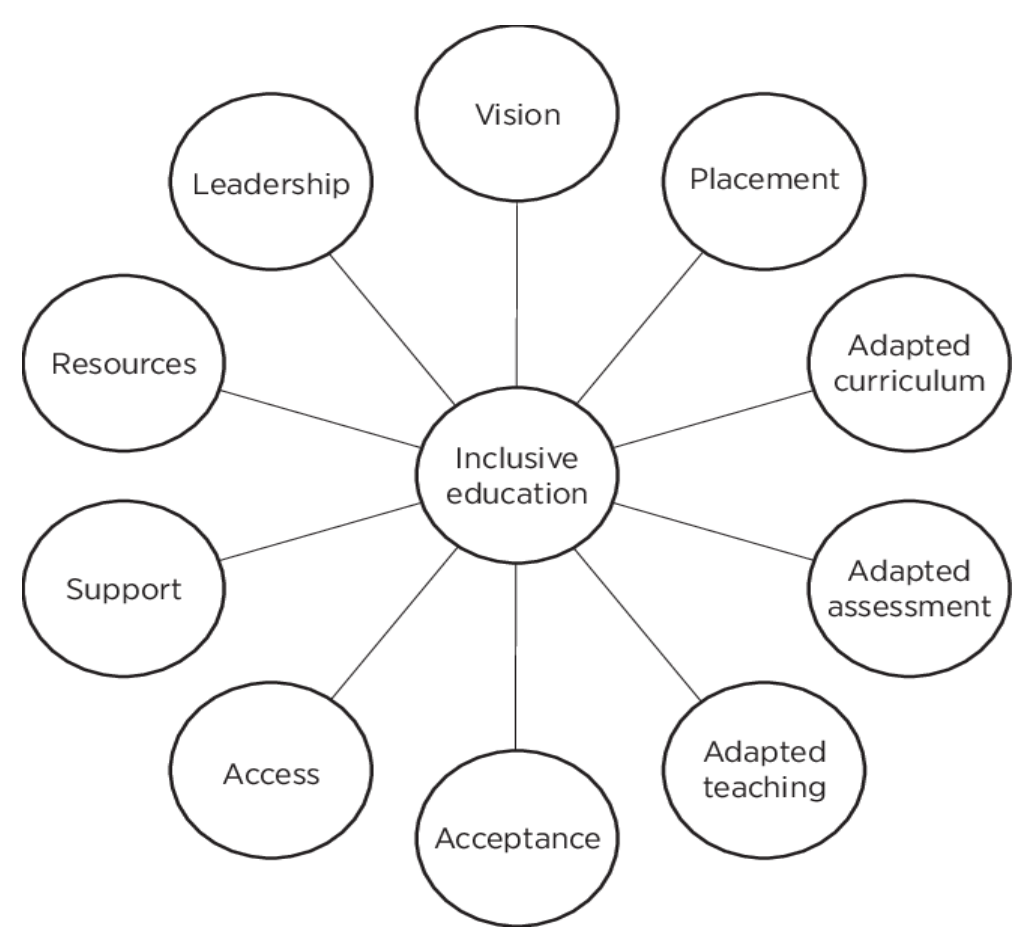

Figure 1: Model of Inclusive Education, (Mitchell, 2015)

\section{Source: Center for Educational Policy Studies Journal}

\section{Parental Attitudes and Concerns Regarding Inclusion of Children}

Parents play a critical part in the perplexing dynamic inclusion process, which begins with the parents' decision to place their special needs child in a conventional learning environment. As a result, during the last two decades, a number of researches have viewed the perspectives of parents of children with and without disabilities on inclusion, yielding contrary results (Leyser \& Kirk, 2004).

\section{Reactions of Parents}

For parents of children with special needs, initially, acceptance becomes the main concern. Parents of children with disabilities believe that inclusion could increase their child's learning ability due to higher standards in a regular class as it provides stimulating environment for learning. Parents reported that the teachers do not accept children with disabilities wholeheartedly as their presence overburden them and classroom environment do not accept and welcome their disabled child (Fatima, Malik \& Ashraf, 2020). Najjingo, (2009) pointed out the teachers and classmates' bleak acceptance level towards the disabled children highlighted by the parents in the classroom environment. All adverse reservations like rejection; 
labeling; bullying; injuries and mishaps can lead parents to overprotect their vulnerable children that impede the process of the child's development (Taller-Azuly, 2015). Parents were reported hesitant in sending their children with disabilities in mainstream setting due to adverse views of teachers and parents of abled peers (Aziz and Madani, 2007; Grigal; Neubert; Moon \& Graham, 2003).

In another study, negative attitudes of the parents of pupils without disabilities were cited by almost all parents of children with disabilities (Farooq, 2013). A study reported that the demands of children with special needs become so great that the teachers have to compromise on the growth and education of their abled peers (Kugelmass, 2006). In a study by Thakur and Abbas, (2017) it was reported that the perceptions of parents of students with disabilities is that children with special needs do not receive enough help from teachers, and the children feel isolated and out of the classroom learning environments. Abled children are forthcoming and welcoming having disabled children in the class that improves their selfworth by helping and supporting them reported by the parents of children with special needs. Parents of children with disabilities have fears that their child would be bullied by their peers (Taub, 2006).

\section{Role of teachers and quality of instruction}

Educators' role in creating an effectual inclusive learning environment is imperative. Lack of in-service teachers' training has become an obstacle in promoting inclusion (Brownell, Smith, Crockett \& Griffin, 2012). Parents feel that teachers are not skilled professionally to tackle a diverse classroom, in particular, children with special needs effectively (Manzoor, Hameed \& Nabeel, 2018). Pre-service courses were not enough to prepare them for the realities of teaching students with a wide range of abilities and behaviors. Teachers reported significant feelings of inadequacy with regard to teaching students with special educational needs (Carol, 2003; Gould \& Vaughn, 2000). Both pre-service and in-service courses that address the skills and attitudes of teachers towards students with disabilities are deemed insufficient by many teachers (Bartak \& Fry, 2004; Gary, 2002; Westwood \& Graham, 2003). In-service general school teachers need training in identifying, assessing, adapting, differentiating curriculum, and managing diversity in the classroom through workshops, which is the duty of the state and school authorities (Darling - Hammond, 2010). Parents highlighted rigid pedagogy and standardized assessment process the reasons of academic failure and drop-outs, when children fail to meet the criteria set by the institutions (Jeynes, 2005). It is the responsibility of the teachers to plan lessons in such a manner that they range from the most basic level to the most sophisticated level, keeping in view the varied cognitive abilities of the learners (Skrebneva, 2015). It is not simple to tackle inclusive classrooms without prior preparation by the teachers. (Westwood, 2018). Good pedagogical approaches that can be used with all children by all teachers may be applied (Palomino, 2017). Hull, (2005) reported that the lack of continuing training for in-service educators also leads to vulnerability, confusion, poor self-esteem, and a lack of creative and productive classroom activities leaving parents of children in uncertainty and distress. According to Price, (2018) serious concerns are often indicated by teachers and researchers when the abilities of teachers are discussed as far as training for inclusive classrooms is concerned to entertain the diverse needs of the students.

According to Takala and Sume (2017), teachers reported that inclusion is successful in Finland due to the practical measures in the form of pedagogical and technical support. Various studies established that parents of children with disabilities are concerned about their child's poor academic performance in inclusive schools, and highlighted lack of teachers' training as a primary reason of this failure (Ainsco, 2005; Ehsan, 2018; Skrebneva, 2015). According to Suprayogi, Valcke \& Godwin, (2017) implementation of differentiated instruction is only possible through teachers' training to deal with diverse learners in inclusive classrooms. 
Following figure illustrates the factors to be emphasized in executing differentiated instruction:

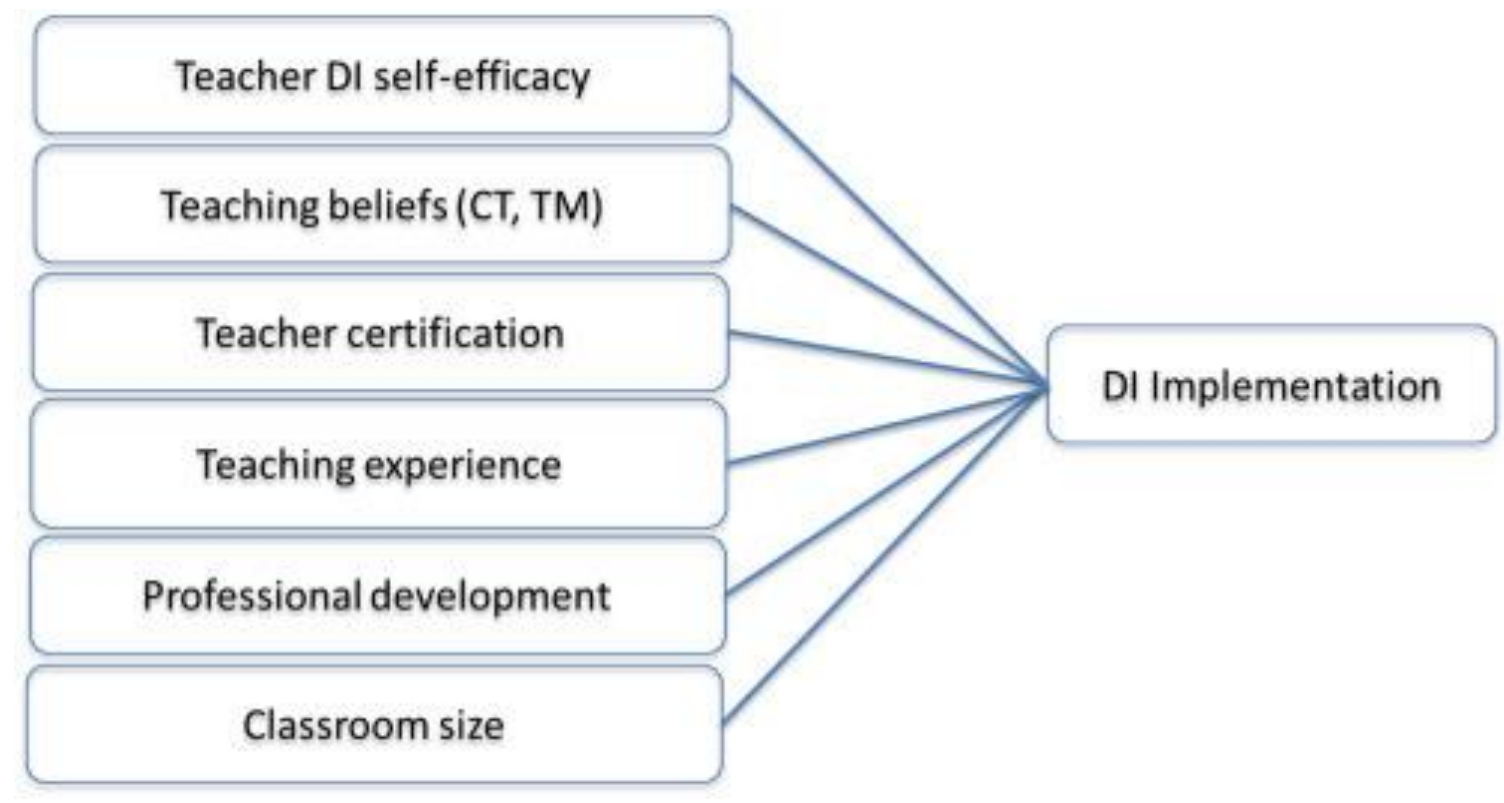

Figure 2: Teachers and their implementation of differentiated instruction in the classrooms Source: Suprayogi, M. N., Valcke, M., \& Godwin, R. (2017).

\section{Class Size and Time Demands}

Inclusive class sizes are often no smaller than other classes, and do not allow room for the additional individualized attention some students need (Westwood \& Graham, 2003). Class size and composition also have obvious implications for inclusive education "smaller classes may have the greatest positive impact on students with greatest educational needs" (Bascia, Nina, 2010). Various researches reported dissatisfaction with the large class sizes, despite the inclusion of students with significant additional needs (Avrimidis, 2000). Although most teachers want to help low-achieving students, but are short of time to prepare special materials (Margolis \& McCabe, 2003). Student's lack of progress is certainly distressing for teachers. Time is also one of the major challenges associated with inclusion (Bartak \& Fry, 2004). Time demands of collaborating with different professionals is also limited. Parents of the abled students have this apprehension that teachers ignore their children in the presence of children with special needs, extra time is given to them, that adversely affects the academic performance of their children (Nketsia, Saloviita \& Gyimah, 2016). Parents of children with disabilities are dissatisfied, and highlighted the aspects of helplessness and isolation of their children in the inclusive classrooms by the teaching staff as they are overburdened and could not manage the time (Akinbola, 2010). Lowering class size can help with inclusion. Large class sizes not only challenge teachers, they also result in students with academic and emotional needs not being able to participate in their classroom resulting in frustration (Jodi \& Sal Mendaglio, 2014). With smaller class sizes, teachers can support students more fulsomely to help them with their learning needs and reduce behavioral challenges (Filges; Schmidt \& Nielsen, 2018).

\section{Institutional Support}

Inclusive education is practically not possible without adequate institutional support. According to Mahlo, (2011), fears of the parents of children with disabilities include unavailability of assistive devices; weak support of related professionals, leading to their children's isolation and non-engagement in varied learning activities. Parents are also concerned how to meet the needs of the learners with impairments in the absence of professionals that include audiologists, psychologists, speech therapists etc. are there to support and meet the needs of learners with impairments (Engelbrecht, 2013; Sibley, 2004). Inclusive education is not successful so far due to lack of teachers' training and required resources in the regular education settings (Loreman, Deppeler \& Harvey, 2005). Hidayat, Gunarhadi and Hidayatullah, (2017) reported that the challenges regarding inclusion were lack of training of the teachers for hearing impaired 
students in inclusive education and shortage of assistive devices. Erbas, (2017) reported that children with disabilities are likely to develop behavior issues and communication gaps that affect their academic performance in the schools and team of related professionals help teachers in filling these gaps (Patil \& Pujar, 2019).

In the schools of Pakistan, parental involvement, counselling and training to be a part of the support program for struggling learners is passive, just restricted to the parent-teachers meeting, and that too, not regularly (Ahmad \& Yousaf, 201; Farooq, 2012). The movement towards inclusion is likely to be disturbed if school administration and staff do not adequately address the concerns and challenges of the parents, since the child's wholesome development is largely dependent on the manner he/she is dealt in the schools (Akhmetzyanova \& Saitgaleeva, 2016; Taub, 2006).

\section{Methodology}

The research study was qualitative in nature, and data was collected through semi-structured interviews. Following research questions directed the study:

1. What are the parents' concerns about inclusion education?

2. What are the factors affecting the attitudes and perceptions of parents with and without disabilities about inclusive education settings?

3. What are the factors influencing the access and participation of children with disabilities in inclusive education?

Population constituted of parents of children with and without disabilities of inclusive primary schools of Punjab. Purposive sampling technique was used to select sample of 10 parents of children with disabilities $(n=5)$ and parents of children without disabilities $(n=5)$ for data collection. Introductory characteristics of the sample is as follows:

Table 1

Parents' introductory characteristics

Characteristics

\section{Gender}

Female (Mothers)

Male (Fathers)

\section{Educational Status}

Illiterate

Primary school graduate

High school graduate

Associate degree

\section{Occupation}

Un-employed

Self-employed

Government job

Private job

\section{Number of children}

1

2

3

4

5

6 n

8

2

An interview guide was developed by the researcher constituting six key questions for conducting in- 
depth interviews. The protocol was validated by the experts of the field and pilot tested on three participants, not included in the sample. Parents were made well-aware of the purpose of the study and ensured of their anonymity and confidentiality. Interviews were audio recorded, transcribed and coded by the researcher. Thematic analysis was used for analyzing the data. The analysis came up with four themes: Acceptance, Quality of instruction, Class sizes and time demands, Institutional support.

Following figure illustrates the four themes derived from the categories of semi-structured interviews.

Figure 3

Themes

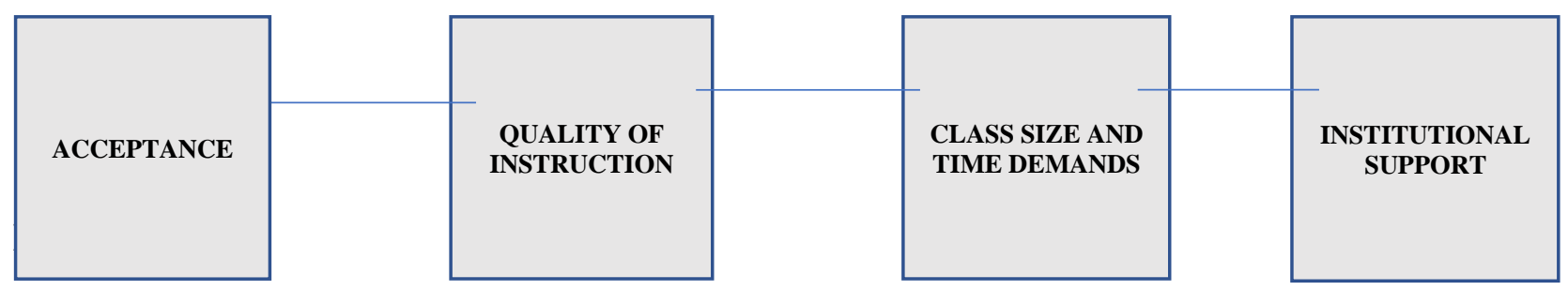

This section provides findings first and then elaborate on the findings with proper quotations from the participants. Responses were categorized into four broad thematic topics below:

\section{Acceptance}

Majority of the parents of the children with disabilities reported that abled peers are quite cooperative and helpful, and do not bully their children, but in very rare case, they are non-cooperative in the learning environment. However, their parents come and complain to the principals about their children without any strong reason most of the times. Parents of abled students are not accepting their children's presence and fear that children with disabilities might hurt or injure their children in the schools and they also take additional support from teachers, whereas their children are ignored. Almost all parents of children without disabilities showed unacceptable attitude towards inclusion of children with disabilities in mainstream schools. Below are the responses of the informants:

One of the mothers reported with grief;

"My daughter is intellectually challenged, and she does not have a destructive behavior or create any problem in the classroom for her peers and teachers. Still teachers and parents are irritable about her behavior and displays rejection. This type of attitude annoys us and cause stress amongst all of us."

One father of the abled son stated,

"I am afraid that my child could be hurt by his intellectually challenged class fellow someday. There are special schools also and such children should be enrolled in those schools. I am upset. I have spoken to the principal, but in vain.

A mother of the hearing-impaired child reported,

"My child enjoys a lot in the school with his hearing peers. His social skills and confidence are boosted. He plays games and enjoys all activities of the classroom. The principal of the school once called and told me that your child is very naughty and beats other children. Parents of other children are not happy with his presence. I could feel discrimination towards my child."

Another mother reported,

"My child is always happy with his class fellows. Although he is wheel-chair bound but his friends try to make his mobility easier. Sometimes, he feels helpless when all students are busy playing in the playground and if he wants to go to the washroom at that time, then nobody comes to facilitate him. Otherwise, he has no problem and feels comfortable in the learning environment."

Another mother reported with sadness,

"I am annoyed with the behavior and attitude of the teachers and parents of the abled peers, as they are not accepting my intellectually child son in the inclusive environment. When my child gets frustrated because of this rejection and isolation in the classroom, he uses foul language out of frustration. The abled peers go back homes and tell their parents. They complain about my child all the times with the headmistress, and insist that my child should be shifted to a special school. I don't want to shift him to a 
segregated special school.”

\section{Quality of Instruction}

Almost all parents of children with disabilities informed that in-service teachers lack professional training while dealing with their children in inclusive classrooms. Teachers use the same teaching technique for all students and do not modify or adapt the teaching approaches and fail in giving extra time and additional support to the children with impairments. Teachers are not sufficiently trained to deal with diverse classroom and differentiated instruction is hardly visible in inclusive learning environment. Majority of the teachers feel overburdened, when they have children with disabilities in their classrooms. However, majority of the parents of children without disabilities were of the view that children with disabilities take more time and attention of the teachers, due to which their children are suffering in academics. Below are the responses of the parents:

One mother said,

"The teacher has appointed my abled child with the intellectually challenged child to guide and help him in performing his tasks, and my child could not complete his own classroom assignment. It is not good. Teachers lack training for inclusion. My son cannot refuse the teacher's order. He also feels good when he helps his disabled peer, but I am afraid, not at the cost of his own work."

A father responded,

"My child with hearing impairment is failing repeatedly in all assessments as teachers do not guide him during assessments and do not give him extra time to complete his test. In addition, the teachers have insufficient knowledge about hearing impairment and inclusive education that is why my child cannot come up to the required standard. Teachers use the same teaching style for the whole class, overlooking my child's sensory impairment. Teachers' training is mandatory for inclusive education. I am quite worried about his future."

One of the mothers informed,

"The quality of instruction is so poor for children with disabilities. Educators use one teaching style for all students, which is disappointing. Teachers are not trained enough to fulfill the requirements of creating successful inclusive learning environment. My daughter with learning disability is isolated in the classroom. The teachers are busy in completing the syllabus ignoring my child's needs and requirements. They are just concerned to satisfy the Headmistress and the parents of children without disabilities as they are more in number. It is sheer discrimination displayed by the teachers for this marginalized segment."

Another mother stated, "I am not comfortable with the presence of children with disabilities in my child's class. Teachers give more attention to them and overlook rest of the children during the classroom activities. I am not happy with this arrangement."

One of the mothers said:

"My child with speech impairment is not improving academically in the inclusive school, however, his confidence level and self-esteem have improved. His speech problem has created a communication gap between him and his teachers. Teachers need proper training to make him include successfully in the teaching-learning process, otherwise there is no use of making him sit in this school isolated and out of all classroom activities." 


\section{Class size and Time Demands}

Majority of the parents blamed the large class size and time constraint for teaching staff as a barrier to inclusion. According to them, due to huge class size, the teachers are unable to give proper time to all students. Most of the parents of children with disabilities were of the view that the teachers give more attention to the abled students as compared to their children in the learning environment of the classroom. Time constraint is one major factor that is impeding effective inclusion of their children. Parents of children without disabilities complained that their children's learning atmosphere is distracted because of the presence of children with impairments. Teachers are puzzled how to manage their timings and class completion of syllabus, as children with disabilities seek more time and additional support in performing their tasks. Teachers ignore the abled students in facilitating them, which is a huge point of concern. Below are the answers of the informants:

One mother stated:

"There are 40 children in the class including four children with impairments. How is it possible for the teachers to make all of them succeed academically, when adequate time is not provided to them. I am not satisfied with the teachers of the school as they are overburdened. They cannot manage the time due to large class size. My child is not performing well in the assessments and I am thinking to shift him to some other school where the class strength is less, otherwise I am afraid he will fail in the annual exams."

Another mother informed,

"My child with intellectual disability is not attended by the teacher due to limited time and large class size. I am very upset. He is isolated and his peers are so much busy in doing their own work. His teachers expect that the peers would help him, but nobody does. I spoke to his teachers, but they are also helpless as they are unable to provide him extra support as they have to complete the syllabus, check notebooks and the class size is out of control and teachers are short of time."

One of the fathers reported,

"Inclusive education setting is quite demanding. The school staff is untrained, overburdened and have time limitations due to which my child is in distress and so are we. There is nothing we can do, only we can request the school principal to hire more staff, as students' ratio is quite high in each section as compared to the staff strength. It is not possible for the staff to accommodate 45 children in the classroom and adequately run the teaching-learning process. My child is always complaining that the teachers do not give him sufficient time and support.

One of the mothers informed,

"There should not be more than 25 children in the class. The students' strength is more and the teaching staff is less in each section. It is not the teacher's fault when he is unable to tackle all children including children with disabilities. Although abled children seem to be suffering more as compared to children with special needs in inclusive settings as due time and attention are not given to them. They help their struggling peers, too during classroom activities and sometimes unable to complete their own classroom assignments. I feel children with disabilities should be shifted to special schools where they would be looked after, and will learn more."

A mother reported in grief,

"My hearing-impaired child is disturbed and lagging behind the rest of the students academically since there is a communication gap between him and teachers. He is isolated in the classroom. He cannot comprehend information, and teachers are not so concerned about it. I feel he is not given much attention as teachers are overworked and 
do not have sufficient time to provide him additional support as they need to complete the syllabus in time. Classroom sizes and time constraints are preventing successful inclusion of children with and without disabilities. The school administration must consider these important factors before enrolling the students."

\section{Institutional Support}

The majority of respondents stated that relevant experts such as audiologist, speech therapist, psychologist, and physiotherapist etc. are not available at a regular basis in schools. Necessary assistance is not offered by the institutions to children with disabilities. Their children are suffering greatly as a result of this team's absence. Most of the parents stated that these professional services are too expensive for them to use in their personal capacity since they are poor, and that all of these service providers demand excessive fees when the child is taken to them for support outside of school. Hearing aids are either being purchased by the parents themselves or are not obtained because hearing aids are costly for them. According to two informants, the school directed their disabled children to public and private hospitals for evaluation and other screening services, which is unaffordable for them due to time and financial constraints. The following are the informants' responses:

One father reported,

"There are no supportive services provided by the institution. I have purchased the hearing aid, which is very expensive. There are no provisions of speech therapist, audiologist and psychologist etc. in the school. My child has some behavior problems due to his communication and speech delay. Secondly, teachers also need help of this team as they are not trained enough to deal with language delay of my child. I am not guided by the schools and the teachers how to make my child improve academically. Due to their absence, our child is suffering a lot. We are poor, so we do not afford all these services from private clinics and hospitals."

One mother informed,

"Only free books are available to the children from school, but there is absence of other provisions to improve the functionality of my hearing-impaired child, like free hearing aid. Presence of audiologist, psychologist, speech therapists etc. are missing. My child is facing a lot of challenges in inclusive setup since there is no collaborative support provided to him from the institution. There is a need of audiologist in the school to check the degree of his hearing loss regularly and to guide teachers how to cope with it. Guidance and counselling services for us are missing. Although the audiologist visits the school once a year, but that is not enough."

A father stated in grief,

"I am so depressed as I am too poor to get the provisions of related professionals for the benefit of my speech-impaired child at my own, and the school is not cooperating with me in this regard. My child feels helpless as he has speech problems and if proper speech therapy is done, he can perform better in the learning environment. His confidence level is getting low due to this impairment which the school is not addressing in a proper manner. Teachers do not guide us in the resolution of various challenges my child is facing in the inclusive school."

\section{A mother responded,}

"I face a lot of hurdles in order to make my child assessed and provided with intervention in the public hospital. The institution does not provide such support to our child. My child with intellectual disability was showing weird behaviour, and his teacher referred me to a psychologist in some private hospital as the school does not have a psychologist. 
I took my child there and when I came to know about the heavy fee, I returned. I feel, it is the responsibility of the schools to ensure the availability of psychologist, otherwise it will become very difficult for my child to survive in inclusive schools, although he enjoys interacting and playing with his peers but that is not enough."

Another mother reported,

"My child is physically impaired, and she needs physiotherapy at regular basis to improve her functional skills. The physio-therapist rarely visits the school, and do not have enough time to do physio-therapy of all children as per requirement. I feel good that my child is getting education in regular schools with abled peers, but what I desperately miss is the consistent presence of physio-therapist and psychologist.. Both these provisions, if provided by schools, will resolve so many problems of the children with disabilities. I can only request to the school administration to hire them as my child is suffering a lot because of their absence."

\section{Discussion and Conclusion}

The move towards inclusive education is relatively slow due to quite a number of unsolved issues in the education system of the country. The public sector has so far failed to bring inclusive education in the public educational settings. A small number of the schools in the private sector has implemented inclusion and have accommodated children with disabilities in primary education (UNICEF, 2017). Parents of children without disabilities show reluctance in accepting the children with disabilities in inclusive primary schools, however the abled peers are quite welcoming and helpful for these children (UNICEF, 2017). Najjingo, (2009) established that parents of children with disabilities are worried about the level of acceptance by the teachers and classmates in the learning environment towards their children. Abled children are forthcoming and welcoming having disabled children in the classroom that improves their self-worth by helping and supporting them reported by the parents of children with special needs (Taub, 2006). Parents of abled children have a perception that their children would be hurt or injured by children with disabilities, and ignored by the teachers, too in inclusive classrooms. Negative attitudes of the parents of pupils without disabilities were cited by almost all parents of children with disabilities, especially those parents who have children with intellectual disabilities (Farooq, 2013). Kugeless, (2006) reported that the demands of children with special needs become so great that the teachers have to compromise on the growth and education of their abled peers in the classroom. Teachers lack training for inclusion and do not use diverse teaching approaches to deal with all children effectively in inclusive learning environment. Poor quality of instruction is preventing the process of inclusion in classrooms. Lack of in-service teachers' training has become an obstacle in promoting inclusion (Brownell; Smith; Crockett \& Griffin, 2012). Parents feel that teachers are not skilled professionally to tackle a diverse classroom, in particular, children with special needs effectively. Sometimes teachers ignore abled children to give additional support to children with impairments according to the parents of children without disabilities, resulting in their weak academic performance.

However, parents of children with disabilities are dissatisfied with the single and fixed teaching style by the teachers for all children as their children are showing poor performance academically in inclusive setups. Differentiated instruction is rarely visible in the existing school environments. Parents highlighted rigid pedagogy and standardized assessment process the reasons of academic failure and drop-outs, when children fail to meet the criteria set by the institutions (Jeynes, 2005). Large class size and time constraint have also proved a barrier to inclusion. Various researches reported dissatisfaction with the large class sizes, due to the inclusion of students with significant additional needs (Avrimidis, 2000). Time is also one of the major challenges associated with inclusion (Bartak \& Fry, 2004). Teachers are overburdened and unable to give proper time to all students in the class, that is a serious point of concern for all parents. Regular parents-teachers meetings and parents' guidance and counseling to be a part of the support program for struggling learners is passive in the schools of Pakistan (Ahmad \& Yousaf, 2011). Absence and insufficient services of the related professionals; weak institutional support; unavailability of assistive 
devices are also impeding the process of inclusion. Children with disabilities are mostly isolated within the inclusive classroom by the teachers. According to Mahlo, (2011), fears of the parents of children with disabilities include unavailability of assistive devices; weak support of related professionals, leading to their children's isolation and non-engagement in varied learning activities. According to Takala and Sume (2017), teachers reported that inclusion was successful in Finland due to the practical measures in the form of pedagogical and technical support. From the discussion, it has been concluded that the status of inclusive education in the country can only be improved if all the retarding factors preventing inclusion highlighted by the parents which include mindsets; teachers' training; differentiated pedagogy; class size and time demands; professional support; parents' guidance and counselling may be taken into consideration by the stakeholders.

\section{Recommendations}

- Parents' guidance and counselling may be made mandatory to resolve issues and misconceptions about inclusion between parents of children with and without disabilities.

- The school management should revisit their educational plans and align with inclusive education approaches.

- Regular in-service teachers training courses focusing on attitudinal change towards inclusive education, including the required knowledge and skills should be conducted by the school management to cater diverse learners in an effective manner.

- The regular schools should ensure the availability of related service providers and assistive devices to children with disabilities, in particular, and for struggling learners in general.

- The schools should seriously consider the class sizes and availability of the teaching staff in accordance with the strength of students before their enrollment to lower the burden of teachers in order to manage time and for smooth running of inclusion process.

- The school department should allocate funds for teacher-training programs at regular basis in mainstream schools.

\section{References}

Ahmad, S., \& Yousaf, M. (2011). Special education in Pakistan: In the perspectives of educational policies and plans. Academic Research International, 1(2), 228-241. http://www.savap.org.pk/.

Ainscow, M. (2005). Developing inclusive education systems: what are the levers for change? Journal of educational change, 6(2), 109-124. https://doi.org/10.1007/s10833-005-1298-4.

Akhmetzyanova, A. I., \& Saitgaleeva, G. G. (2016). Education for parents with disabled children: How to participate in inclusive education support. International Electronic Journal of Mathematics Education, 11(4), 859-865. https://www.iejme.com/article/education-for-parents-with-disabledchildren-how-to-participate-in-inclusive-education-support.

Akinbola, B. R. (2010). The right to inclusive education in Nigeria: Meeting the needs and challenges of children with disabilities. African Human Rights Law Journal, 10(2), 457-477. https://hdl.handle.net/10520/EJC51923.

Avramidis, E., Bayliss, P., \& Burden, R. (2000). A survey into mainstream teachers' attitudes towards the inclusion of children with special educational needs in the ordinary school in one local education authority. Educational psychology, 20(2), 191-211. https://doi.org/10.1080/713663717.

Aziz, H., \& Madani, M. (2007). Parental involvement in the education of their school going disabled children: $\quad$ Reflexions, $\quad 7 \quad$ 26-28. http://citeseerx.ist.psu.edu/viewdoc/download?doi=10.1.1.578.1710\&rep=rep1\&type=pdf\#page= $\underline{26}$.

Bartak, L., \& Fry, J. (2004). Are students with special needs in mainstream classes adequately supported? Australian Journal of Learning Disabilities, $9(1), \quad$ pp 16-21. https://doi.org/10.1080/19404150409546750.

Bascia, N. (2010). Reducing class size: What do we know. Ontario Institute for Studies in Education. https://www.edcan.ca/wp-content/uploads/CEA-2010-Class-

Size.pdf. 
Brownell, M. T., Smith, S. J., Crockett, J. B., \& Griffin, C. C. (2012). Inclusive Instruction: EvidenceBased Practices for Teaching Students with Disabilities. What Works for Special-Needs Learners Series. Guilford Publications. https://eric.ed.gov/?id=ED532844.

Bussing, R., Gary, F. A., Leon, C. E., Garvan, C. W., \& Reid, R. (2002). General classroom teachers' information and perceptions of attention deficit hyperactivity disorder. Behavioral Disorders, 27(4), 327-339. https://doi.org/10.1177\%2F019874290202700402.

Carroll, A., Forlin, C., \& Jobling, A. (2003). The impact of teacher training in special education on the attitudes of Australian preservice general educators towards people with disabilities. Teacher education quarterly, 30(3), 65-79. https://www.jstor.org/stable/23478441.

Carrington, S., Bourke, R., \& Dharan, V. (2012). Using the index for inclusion to develop inclusive school communities. Teaching in inclusive school communities, 341-366. https://eprints.qut.edu.au/55150/.

Cohen, D. K., \& Ball, D. L. (1999). Instruction, capacity, and improvement. Consortium for Policy Research in Education. https://files.eric.ed.gov/fulltext/ED431749.pdf.

Darling-Hammond, L. (2010). Evaluating teacher effectiveness: How teacher performance assessments can measure and improve teaching. Center for American Progress. https://eric.ed.gov/?id=ED535859.

Duhaney, L. M. G., \& Salend, S. J. (2004). Parental perceptions of inclusive educational placements. Special Educational Needs and Inclusive Education: Inclusive education, 2(2), 363. https://books.google.com.pk/.

Ehsan, M. (2018). Inclusive Education in Primary and Secondary Schools of Pakistan: Role of Teachers. American Scientific Research Journal for Engineering, Technology, and Sciences (ASRJETS), 40(1), 40-61. https://asrjetsjournal.org/index.php/American_Scientific_Journal/article/view/3684.

Engelbrecht, P. (2013). Teacher education for inclusion, international perspectives. European Journal of Special Needs Education, 28(2),115-8 . https://doi.org/10.1080/08856257.2013.778110.

Erbas, E. (2017). Strategies That Teachers Use to Support the Inclusion of Students Who Are Deaf and Hard of Hearing (Doctoral dissertation), Indiana University, Indiana, US.

Farooq, M. S. (2012). Problems faced by students with special needs in ordinary Pakistani schools. Journal of Quality and Technology Management, 8(1), 13-27. http://pu.edu.pk/.

Farooq, M. S. (2013). An Inclusive Schooling Model for the Prevention of Dropout in Primary Schools in Pakistan. Bulletin of Education and Research, 35(1), 47-74. https://eric.ed.gov/?id=EJ1210483.

Fatima, G., Malik, M., \& Ashraf, S. (2020). Parental Satisfaction and Involvement in the Provision of Early Childhood Special Education to their Young Children with Deafness. Journal of Business and Social Review in Emerging Economies, 6(4), 1255-1266. https://doi.org/10.26710/jbsee.v6i4.

Filges, T., Sonne-Schmidt, C. S., \& Nielsen, B. C. V. (2018). Small class sizes for improving student achievement in primary and secondary schools: a systematic review. Campbell Systematic Reviews, 14(1), 1-107.

Gould, A., \& Vaughn, S. (2000). Planning for the inclusive classroom: Meeting the needs of diverse learners. Catholic Education: A Journal of Inquiry and Practice,3(3), 363-374. https://doi.org/10.4073/csr.2018.10.

Grigal, M., Neubert, D. A., Moon, M. S., \& Graham, S. (2003). Self-determination for students with disabilities: Views of parents and teachers. Exceptional Children,70(1), 97-112. https://doi.org/10.1177\%2F001440290307000106.

Hameed, A. (2009). Information and communication technologies as a new learning tool for the deaf. Relation, 10(1), 56-78. http://www.iaeng.org/publication/WCECS2007/WCECS2007_pp468472.pdf.

Hidayat, L., Gunarhadi, G., \& Hidayatulloh, F. (2017). Multi media based learning materials for deaf students. European Journal of Special Education Research, 8(2), 137-146. https://doi.org/10.5281/zenodo.376744.

Hull, J. R. (2005). General Classroom and Special Education Teachers' Attitudes Toward and Perceptions of Inclusion in Relation to Student Outcomes (Doctoral dissertation), University of West Florida.

Jeynes, (2005). A meta-analysis of the relation of parental involvement to urban elementary school student 
academic Uchievement. Urban 40(3):237-69. https://doi.org/10.1177\%2F0042085905274540.

Kugelmass, J.W. (2006). Sustaining cultures of inclusion: The value and limitation of cultural analyses. European Journal of Psychology of Education, 3, 279-293. https://link.springer.com/article/10.1007/BF03173416.

Leyser, Y., \& Kirk R. (2004). Evaluating inclusion: an examination of parent views and factors influencing their perspectives. International Journal of Disability, Development and Education, 51(3), 271285. https://doi.org/10.1080/1034912042000259233.

Loreman T. \& Harvey D., 2005, Inclusive education. A practical guide to supporting diversity in the classroom, Routledge, Abingdon. https://books.google.com.pk/.

Mahlo, F. D. (2011). Experiences of learning support teachers in the foundation phase with reference to the implementation of inclusive education in Gauteng (Doctoral dissertation). University of South Africa, Pretoria. https://uir.unisa.ac.za/handle/10500/5692.

Manzoor, A., Hameed, A., \& Nabeel, T. (2018). Voices of parents about their out of school children with disabilities. Journal of Inclusive Education, 2(1), 77-92. https://jie.aiou.edu.pk/.

Mapolisa, T., \& Tshabalala, T. (2013). The impact of inclusion of children with hearing impairment into regular schools: A case study of Dakamela primary school in Zimbabwe. International Journal of Asian Social Science, 3(7), 1500-1510. https://www.researchgate.net/.

Margolis, H., \& McCabe, P. P. (2003). Self-efficacy: A key to improving the motivation of struggling learners. Preventing School Failure: Alternative Education for Children and Youth, 47(4), 162-169. https://doi.org/10.1080/10459880309603362.

Mitchell, D. (2015). Inclusive education is a multi-faceted concept. Center for Educational Policy Studies Journal, 5(1), 9-30. https://ojs.cepsj.si/index.php/cepsj/article/view/151.

Najjingo, H. (2009). Challenges of accessing all-inclusive education services by children with disabilities (Cwds): A case of Mijwala Sub-County Ssembabule District (Unpublished Dissertation of Masters of Arts). Social Sector Planning and Management of Makerere University. https://www.mak.ac.ug/documents/Makfiles/theses/Najjingo_Hellen.pdf.

Nketsia, W., Saloviita, T., \& Gyimah, E. K. (2016). Teacher Educators' Views on Inclusive Education and Teacher Preparation in Ghana. International Journal of Whole Schooling, 12(2), 1-18. https://jyx.jyu.fi/handle/123456789/51497.

Palomino, M. D. C. P. (2017). Teacher training in the use of ICT for inclusion: differences between early childhood and primary education. Procedia-Social and Behavioral Sciences, 237, 144-149. https://doi.org/10.1016/j.sbspro.2017.02.055.

Peebles, J., \& Mendaglio, S. (2014). Preparing teachers for inclusive classrooms: Introducing the individual direct experience approach. Learning Landscapes, 7(2), 245-257. https://doi.org/10.36510/learnland.v7i2.663.

Pomerantz, E. M., Moorman, E. A., \& Litwack, S. D. (2007). The how, whom, and why of parents' involvement in children's academic lives: more is not always better. Review of educational research, 77(3), 373-410. https://doi.org/10.3102\%2F003465430305567.

Price, R. (2018). Inclusive and special education approaches in developing countries. Roz Price Institute of Development Studies, London: UK. https://opendocs.ids.ac.uk/opendocs/handle/20.500.12413/14284.

Pujar, L., \& Patil, S. (2019). Emotional intelligence among hearing impaired children. International Journal of Current Microbiology and Applied Sciences, 8(9), 1818-1824. https://www.ijcmas.com/aug2019issue.php.

Sibley, K. A. (2004). Twice exceptional. In Klein, S. D. \& Kemp, J. D. (Eds.), Reflections from a different journey: What adults with disabilities wish all parents knew (pp. 156-160). New York: McGrawHill.

Singal, N., Sabates, R., Aslam, M., \& Saeed, S. (2020). School enrolment and learning outcomes for children with disabilities: findings from a household survey in Pakistan. International Journal of Inclusive Education, 24(13), 1410-1430. https://doi.org/10.1080/13603116.2018.1531944.

Skrebneva, I. V. (2015). Guidelines to curriculum adaptations to support deaf learners in inclusive 
secondary schools (Doctoral dissertation), University of South Africa, South Africa. https://uir.unisa.ac.za/handle/10500/19838.

Suprayogi, M. N., Valcke, M., \& Godwin, R. (2017). Teachers and their implementation of differentiated instruction in the classroom. Teaching and Teacher Education, 67, 291-301. https://doi.org/10.1016/j.tate.2017.06.020.

Takala, M., \& Sume, H. (2018). Hearing-impaired pupils in mainstream education in Finland: Teachers' experiences of inclusion and support. European Journal of Special Needs Education, 33(1), 134147. https://doi.org/10.1080/08856257.2017.1306965.

Taller-Azulay, G., \& Rusu, A. S. (2015). Parents' Involvement in Supporting Education of Hearing Impaired Children in Israel. Procedia-Social and Behavioral Sciences, 209, 188-194. https://doi.org/10.1016/j.sbspro.2015.11.213.

Taub, D. J. (2006). Understanding the concerns of parents of students with disabilities: Challenges and roles for school counselors. Professional School Counseling, 10(1). https://doi.org/10.1177\%2F2156759X0601001S07.

Thakur, I., \& Abbas, F. (2017). Inclusive Education in Punjab: Challenges and Way Forward. Journal of Inclusive Education, $1(1)$

$15-26$. http://journal.aiou.edu.pk/journal1/index.php/JIE/article/view/20.

Timmons, V., \& Alur, M. (2004). Transformational Learning: A Description of How Inclusionary Practice Was Accepted in India. International Journal of Special Education,19(1), 38-48. https://eric.ed.gov/?id=EJ852041.

UNESCO (2009). Inclusion of children and disabilities: the early childhood imperative. UNESCO Policy Brief on Early Childhood. Retrieved http://unesdoc.unesco.org/images/0018/001831/183156e.pdf.

UNICEF. (2003). Examples of inclusive education in Pakistan. The United Nations Children's Fund. retrieved from: http// www.uncef.org

UNICEF. (2017). Children with Disabilities. Towards Inclusive Education in South Asia. (Unpublished, Consolidated Report). UNICEF Regional Office for South Asia. : http// www.uncef.org.

Vegas, E., \& Winthrop, R. (2020). Global Education: How to Transform School Systems? Reimagining the Global Economy: Building Back Better in a Post-COVID-19 World. Center for Universal Education at The Brookings Institution. https://eric.ed.gov/?id=ED610536.

Westwood, P. (2018). Inclusive and adaptive teaching: Meeting the challenge of diversity in the classroom. London: Routledge. https://www.taylorfrancis.com/books/mono/10.4324/9781351061261/inclusive-adaptiveteaching-peter-westwood.

Westwood, P., \& Graham, L. (2003). Inclusion of students with special needs: Benefits and obstacles perceived by teachers in New South Wales and South Australia. Australian Journal of Learning Difficulties, 8(1), 3-15. https://doi.org/10.1080/19404150309546718. 